\title{
Systemic Inflammatory Response in Unilateral Sinonasal Polyps
}

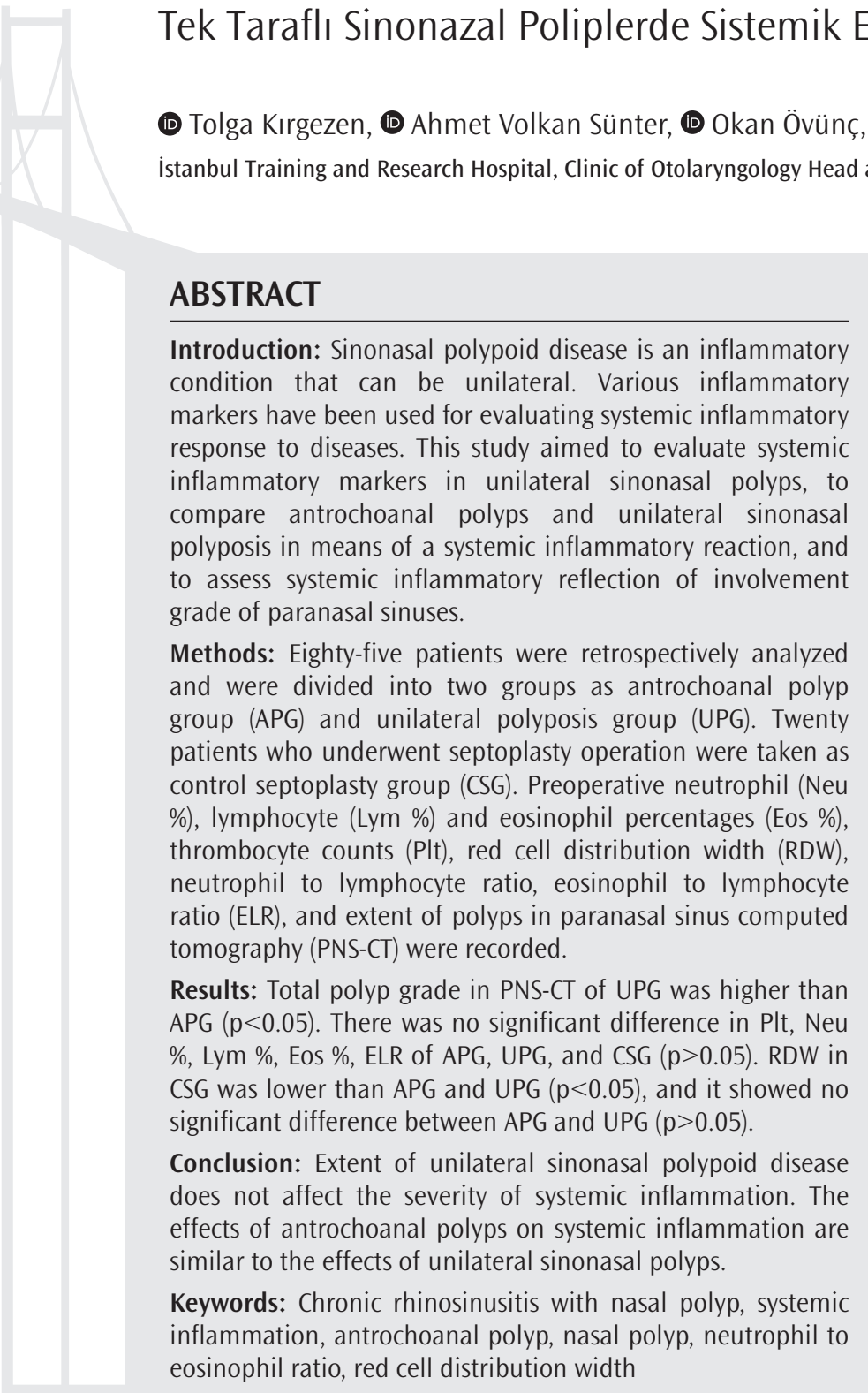

\section{ÖZ}

Amaç: Sinonazal polipler kronik sinonasal enflamasyon sonrasında gelişen tek taraflı da olabilen patolojilerdir. Çeşitli kan parametreleri sistemik enflamasyon cevabını değerlendirmede kullanılmaktadır. Bu çalışmada amaçlarımız; tek taraflı nazal poliplerde sistemik enflamasyon işaretçilerini incelenmesi, tek taraflı sinonazal hastalık ve antrokoanal polipler arasında sistemik enflamatuar cevap açısından fark olup olmadığının görülmesi ve paranazal sinüslerdeki polipoid hastalığın sistemik enflamasyona yansımasının araștırılmasıdır.

Yöntemler: Retrospektif olarak 85 hasta iki gruba ayrılarak incelendi: Antrokoanal polip grubu (APG), unilateral sinonazal polip grubu (UPG). Septoplasti operasyonu yapılan 20 hasta da kontrol grubu (CSG) olarak alındı. Preoperatif nötrofil, lenfosit ve eozinofil yüzdeleri, trombosit sayısı (Plt), eritrosit dağılım genişliği (RDW), nötrofil lenfosit oranı, eozinofil lenfosit oranı (ELR), paranazal sinüs bilgisayarlı tomografisindeki (PNS-BT) polip yaygınlığı kaydedildi.

Bulgular: UPG'deki polip yaygınlığı, APG'ye göre daha fazlaydı $(p<0.05)$. Plt, nötrofil, eozinofil, lenfosit yüzdeleri, ELR; APG, UPG ve CSG arasında anlamlı fark göstermedi ( $p>0,05)$. APG ve UPG'de RDW değeri CSG'ye göre yüksekti $(p<0,05)$ ancak APG ve UPG arasında fark göstermiyordu ( $p>0,05)$.

Sonuç: Tek taraflı sinonazal poliplerin yaygınlığı sistemik enflamasyon yanıtının şiddetini etkilemez. Antrokoanal polipler ve tek taraflı sinonazal poliplerin sistemik enflamasyona etkileri benzerdir.

Anahtar Kelimeler: Nazal polipli kronik rinosinüzit, sistemik enflamasyon, antrokoanal polip, nazal polip, nötrofil iyozinofil oranı, eritrosit dağılım genișliği

\section{Introduction}

Chronic rhinosinusitis that affects $4-10 \%$ of people worldwide is defined as the inflammatory condition of the paranasal sinuses and nasal passages, lasting for at least 12 weeks. The inflammation is named as chronic rhinosinusitis with nasal polyps when there is visible polyp tissue in the middle nasal meatus (1).

Nasal polyps are diagnosed by anterior rhinoscopy and nasal endoscopy. Paranasal sinus computed tomography (PNS-CT) shows the disease
Address for Correspondence/Yazıșma Adresi: Tolga Kırgezen MD, İstanbul Training and Research Hospital, Clinic of Otolaryngology Head and Neck Surgery, İstanbul, Turkey

Phone: +9021245964 40 E-mail: tolgakirgezen@gmail.com ORCID ID: orcid.org/0000-0003-1965-6408

Cite this article as/Atıf: Kırgezen T, Sünter AV, Övünç 0 , Yiğit Ö. Systemic Inflammatory Response in Unilateral Sinonasal Polyps. İstanbul Med J 2020; 21(1): 58-63.
Received/Geliș Tarihi: 18.11.2019 Accepted/Kabul Tarihi: 10.12.2019

(c) Copyright 2020 by the Istanbul Training and Research Hospital/istanbul Medical Journal published by Galenos Publishing House.

(C) Telif Hakkı 2020 İstanbul Ĕğitim ve Araștırma Hastanesi/Istanbul Tıp Dergisi, Galenos Yayınevi tarafından basılmıștır. 
extent. Generally, polyps are multiple, bilateral, and seen in 1-4\% of the population. They mostly accompany chronic rhinosinusitis. A nasal polyp is characterized by progressive inflammation of sinonasal mucosa in which eosinophils, T-cells, neutrophils, and plasma cells are present (2).

They result from edematous changes in inflamed sinonasal mucous membranes, and cause nasal congestion and discharge, headache, and olfactory dysfunction. They are seen mostly in patients of 40-70 years old and they are rarely seen under the age of 10 (3).

Histopathologically, nasal polyps are characterized by thickening of the basement membrane, formation of the atypic glands, goblet cell hyperplasia, infiltration of the inflammatory cells, and subepithelial edema. Eosinophils are the most common inflammatory cells. Inflammatory mediators, cytokines, adhesion molecules, and endothelial receptors involve in (4).

Multiple hypotheses for their unknown ethiopathogenesis were suggested in the literature, such as chronic inflammation, environmental pollution, aspirin intolerance, allergy, genetic, hereditary, and environmental problems. They have a multifactorial pathology (5).

The solitary, benign soft-tissue masses extending into the nasopharynx that originate from the nasal cavity are called choanal polyps. Their common origin is maxillary sinus mucosa, and the name is antrochoanal polyp. They constitute 3-6\% of nasal polyps in all population and 35\% of pediatric nasal polyps. The medical treatment is useless and the treatment is surgery (6).

Ethiopathogenesis is still not known. Although, they were suggested to be due to complication of chronic antral inflammation, allergic polyps (more eosinophils) are found more frequently than the inflammatory polyps (more neutrophils) (7).

In literature, the ratios of neutrophil to lymphocyte (NLR), platelet to lymphocyte $(P L R)$, eosinophil to lymphocyte ratio (ELR), and eosinophil count and red blood cell distribution width (RDW) value that can be simply obtained from complete blood count have been studied for a correlation with nasal polyp severity and recurrence. In sinonasal polyposis, the correlation was explained by the eosinophilrich inflammation and chronic inflammation that causes the body to produce lymphopenia, thrombocytosis, and neutrophilia (8-10).

The aim of this study was to evaluate the systemic inflammatory markers in unilateral sinonasal polypoid disease, to show if antrochoanal polyps and unilateral sinonasal polyposis results in different systemic inflammatory reactions and whether these possible changes in inflammatory status is reflected by extent of disease seen on PNS-CT and endoscopic nasal examination.

\section{Methods}

Our study was approved by the University of Health Sciences, İstanbul Training and Research Hospital Local Clinical Research Ethics Committee on August 29th 2019 , with the decision number of 1958 (decision no: 2011-KAEK-50).

The patients, who underwent unilateral functional endoscopic sinus surgery and antrochoanal polyp excision surgery with indications of unilateral sinonasal polyposis or antrochoanal polyp, respectively, in our otolaryngology clinic between January 2014 and August 2019, were analyzed. Informed consent was taken from all patients for their surgeries and the use of their medical data in academic medical research. A total of 85 patients ( 55 male, 30 female) were included in our study. Twenty patients who were operated for nasal septum deviation (septoplasty operation) in the same period (with no acute or chronic inflammation, nasal or systemic disease) were taken as control septoplasty group (CSG).

The patients with chronic diseases, malignancies, chronic sinusitis without nasal polyposis, hypothyroidism, malnutrition, obstructive sleep apnea, allergic rhinitis, acute or chronic infections, parasitic infections, atopic conditions, asthma, familial history of atopy or allergy, patients who used systemic medications or steroid recently or used preoperative oral steroids were excluded from the study. Bilateral sinonasal disease and recurrent sinonasal disease were also excluded from the study. The patients, whose surgical specimen was analyzed pathologically and diagnosed as other than inflammatory polyp, were also excluded.

The patients were divided into two groups, namely antrochoanal polyp group (APG) and unilateral polyposis group (UPG). Preoperative records of laboratory tests and PNS-CT scans of all patients were analyzed. PNS-CT scans were screened for the involvement of the sinuses, burden of disease, and scoring was done according to the modified Lund-Mackay system (11) [no polyp: 0 point, partial sinus involvement: 1 point, complete involvement in sinüs: 2 points; osteomeatal complex disease: 2 points, no disease in osteomeatal complex: 0 points for every unilateral paranasal sinus (maxillary, ethmoid, frontal and sphenoid sinuses)]. A total unilateral involvement score is obtained from the summation of these points.

At the endoscopic nasal examination, the size of the polyps was scored according to extension volume in nasal cavity (12) (polyp grading system: 0 , no visible nasal polyp; 1 , small amount of polypoid disease confined within the middle meatus; 2 , multiple polyps occupying the middle meatus; 3 , polyps extending beyond the middle meatus, within the sphenoethmoid recess but not totally obstructing, or both; 4, massive polyps completely obstructing the nasal cavity).

For every patient; neutrophil (Neu \%), lymphocyte (Lym \%) and eosinophil percentages (Eos \%), thrombocyte counts (PIt), RDW values were recorded, NLR, ELR were calculated from their preoperative complete blood counts. These values were compared between the groups.

Associations between complete blood count parameters and PNS-CT scores, the extent of polypoid disease, size of the polyps at endoscopic nasal examinations were analyzed, and both groups (APG and UPG) were compared in means of systemic inflammatory response markers.

\section{Statistical Analysis}

SPSS 22.0 program was used to evaluate all data obtained in the study. Descriptive statistics (mean and standard deviation, median, lowest and highest frequencies, and ratio values) were used to evaluate the data. Kolmogorov-Smirnov test was used for analyzing the distribution of the variables. ANOVA, Kruskal-Wallis, and Mann-Whitney $U$ tests were used for the analysis of the independent quantitative data. A chi-square test was used for the analysis of independent data. 


\section{Results}

A total of 85 patients ( 55 male, 30 female, mean age: 22.63 years and age range: 5-56 years) were included (APG included 31 male and 20 female patients with a mean age of 22.63 years age range of 5-52 years; UPG included 24 male and 10 female patients with a mean age of 36.12 years and age range of 12-56 years). Ranges and mean values of measured parameters are shown in Table 1.

The mean age of the patients in APG and CSG was significantly lower than in UPG $(p<0.05)$. The mean age of the patients in CSG was significantly higher than that of APG $(p<0.05)$. Total polypoid disease grade in PNS-CT of UPG was higher than that of APG $(p<0.05)$. The endoscopic examination of polyp grade in APG was higher than in UPG $(p<0.05)$. There was no significant difference in Plt, Neu \%, Lym \%, Eos \%, ELR values of APG, UPG, and CSG $(p>0.05)$. RDW value in CSG was lower than that of APG and UPG $(p<0.05)$. RDW value showed no significant difference between APG and UPG ( $p>0.05)$. NLR value was higher in CSG than in APG and UPG $(p<0.05)$. NLR value showed no significant difference between APG and UPG ( $p>0.05$ ) (Table 2).

\section{Discussion}

The number of biochemistry, microbiology, and immunology studies regarding nasal polyps is growing in the last years.

Sinonasal polyps are characterized by chronic inflammation causing stromal edema. Nasal polyp epithelial cells produce many inflammatory cytokines, including interleukin-8 (IL-8), granulocyte-macrophage colony-stimulating factor, IL-6, IL-1B, Tumor necrosis factor-alpha, and vascular endothelial growth factor. These cytokines cause eosinophilia because they increase the peripheral circulation of eosinophils (13).
There are few studies for antrochoanal polyps and inflammation. In the literature, the relationship between antrochoanal polyps and allergy was examined, and different results were obtained $(14,15)$.

Neutrophils, lymphocytes, and thrombocytes are functionary blood cells in inflammatory processes. Thrombocytosis, neutrophilia, and peripheral lymphopenia reflect the inflammatory status of the whole body, according to previous studies in the literature. An increased neutrophil count is a reflection of ongoing inflammation, and low lymphocyte count reflects malnutrition and inflammatory status (16-18).

It was reported that there is a correlated increase of NLR with poor clinical progress in cardiac disorders and malignancies $(19,20)$. Like NLR, the increased RDW was also shown as an indicator of systemic inflammation (21).

Thrombocyte to lymphocyte ratio (TLR) was found high and was suggested as a poor prognostic factor in various peripheral vascular and coronary artery diseases, some gynecologic, and hepatobiliary malignancies. In the terminal stage of renal failure, TLR was reported to be more valuable than NLR value in means of indicating the systemic inflammation (22).

In a study, Ulu et al. (23) found that NLR value was significantly higher than the control group in idiopathic sudden sensorineural hearing loss. In patients whose NLR value was higher, the positive response to the treatment was lower. According to these findings, they suggested it as a poor prognostic factor. In Bucak et al. (24) study on Bell's palsy, they found neutrophil and NLR value to be significantly higher than the healthy control group.

The sinonasal polyps and inflammation were examined in various studies. Total serum immunoglobulin $\mathrm{E}$ and eosinophil values were shown to be significantly higher in sinonasal polyposis than in the

\section{Table 1. Ranges and mean values of measured parameters}

\begin{tabular}{|c|c|c|c|c|c|c|c|c|}
\hline \multirow{2}{*}{\multicolumn{2}{|c|}{ Age }} & \multicolumn{3}{|c|}{ Minimum-maximum } & \multirow{2}{*}{$\begin{array}{l}\text { Median } \\
27.0\end{array}$} & \multicolumn{3}{|c|}{ Mean \pm SD } \\
\hline & & 5.0 & - & 56.0 & & 28.1 & \pm & 12.8 \\
\hline Gender & Female & - & - & - & - & 33 & - & $31.4 \%$ \\
\hline \multicolumn{2}{|l|}{ PLT } & 131.0 & - & 405.0 & 252.0 & 254.5 & \pm & 56.2 \\
\hline \multicolumn{2}{|l|}{ RDW } & 11.2 & - & 34.2 & 13.1 & 13.8 & \pm & 3.2 \\
\hline \multicolumn{2}{|l|}{ NLR } & 0.2 & - & 10.0 & 1.8 & 2.3 & \pm & 1.7 \\
\hline \multicolumn{2}{|l|}{ Eo $\%$} & 0.4 & - & 13.0 & 2.0 & 2.7 & \pm & 2.3 \\
\hline \multicolumn{2}{|l|}{ ELR } & 0.0 & - & 0.6 & 0.1 & 0.1 & \pm & 0.1 \\
\hline \multicolumn{2}{|l|}{ Ethmoid } & 0.0 & - & 2.0 & 1.0 & 0.8 & \pm & 0.7 \\
\hline \multicolumn{2}{|l|}{ OMC } & 0.0 & - & 2.0 & 2.0 & 1.8 & \pm & 0.6 \\
\hline \multicolumn{2}{|c|}{ Total PNS-CT Score } & 1.0 & - & 10.0 & 5.0 & 5.0 & \pm & 1.9 \\
\hline \multicolumn{2}{|c|}{ Endoscopic polyp grade } & 1.0 & - & 4.0 & 3.0 & 3.0 & \pm & 0.8 \\
\hline
\end{tabular}

SD: standard deviation, Plt: thrombocyte count, RDW: red cell distribution width, Neu: neutrophil, Lym: lymphocyte, NLR: neutrophil to lymphocyte ratio, Eo: eosinophil, ELR: eosinophil to lymphocyte ratio, OMC: osteomeatal complex 
healthy control group (25). Peripheral blood eosinophil count and ELR were reported as relevant with recurrences of sinonasal polyposis in chronic rhinosinusitis $(10,26)$.

In the study of Atan et al. (9), they found significantly higher leucocyte and thrombocyte counts in bilateral sinonasal polyposis than in the healthy control group. They also found higher TLR, but that was not significant. In this study, NLR and TLR were shown to be not associated with the extent of polyp disease in PNS-CT.

In the study of Tecimer et al. (27), unlike other studies in literature, no association was found between neutrophilic or eosinophilic nature of sinonasal polyposis and polyp recurrences. In Boztepe et al.'s (28) study, they suggested that NLR could be used for the prediction of recurrences in sinonasal polyposis before surgery.

Chronic rhinosinusitis with sinonasal polyposis is mostly bilateral, but it can also be unilateral. In literature, the studies concerning nasal polyps and inflammation are mostly performed in bilateral disease. For this reason, unilateral polyposis and its effects on systemic inflammatory responses were preferred for this study.

Comparing antrochoanal polyps with bilateral sinonasal polyposis would be an imbalanced challenge due to the extent and burden of polypoid disease; so unilateral polyps were preferred for study. Systemic inflammation burden, type, and the differences between the groups were studied.

Steroids are effective in the treatment of sinonasal polyposis. The topical or systemic steroids block the inflammatory signal that is activated by vasoactive mediators (29). They reduce eosinophilia by lowering the granulocyte-macrophage colony-stimulating factor synthesis and increasing eosinophil apoptosis (30). For all bilateral sinonasal polyp patients, preoperative systemic steroid use is routinely preferred in our clinic. Steroids have effects on complete blood count parameters and inflammation (29). In unilateral sinonasal polyps and antrochoanal polyps, preoperative use of steroids is not preferred in our clinic. This is another reason for taking unilateral disease into this study.

Like neutrophil lymphocyte ratio, increased RDW has also been reported as an inflammatory marker in the literature (21). In our study, Plt, Neu \%, Lym \%, Eos \%, ELR values showed no statistically significant differences between the groups. Only the RDW value was significantly higher in UPG and APG than CSG. This value had no significant difference between the UPG and APG.

Although PNS-CT polypoid disease involvement grade score was significantly higher than antrochoanal polyp disease in unilateral sinonasal polyposis disease, this extension grade or polyp volume burden could not create a difference in systemic inflammation. Antrochoanal polyps and unilateral sinonasal polypoid disease increase systemic inflammation; however, they do not have significant differences in systemic inflammation response relative to each other.

The main limitation of our study was that previously established inflammatory indicators like C-reactive protein were not analyzed. These are not used in routine preoperative patient preparation. The large-scaled prospective studies measuring multiple inflammatory parameters may help better explain the relation between sinonasal polyposis and systemic inflammation.

Table 2. Comparison of blood and computed tomography parameters between groups

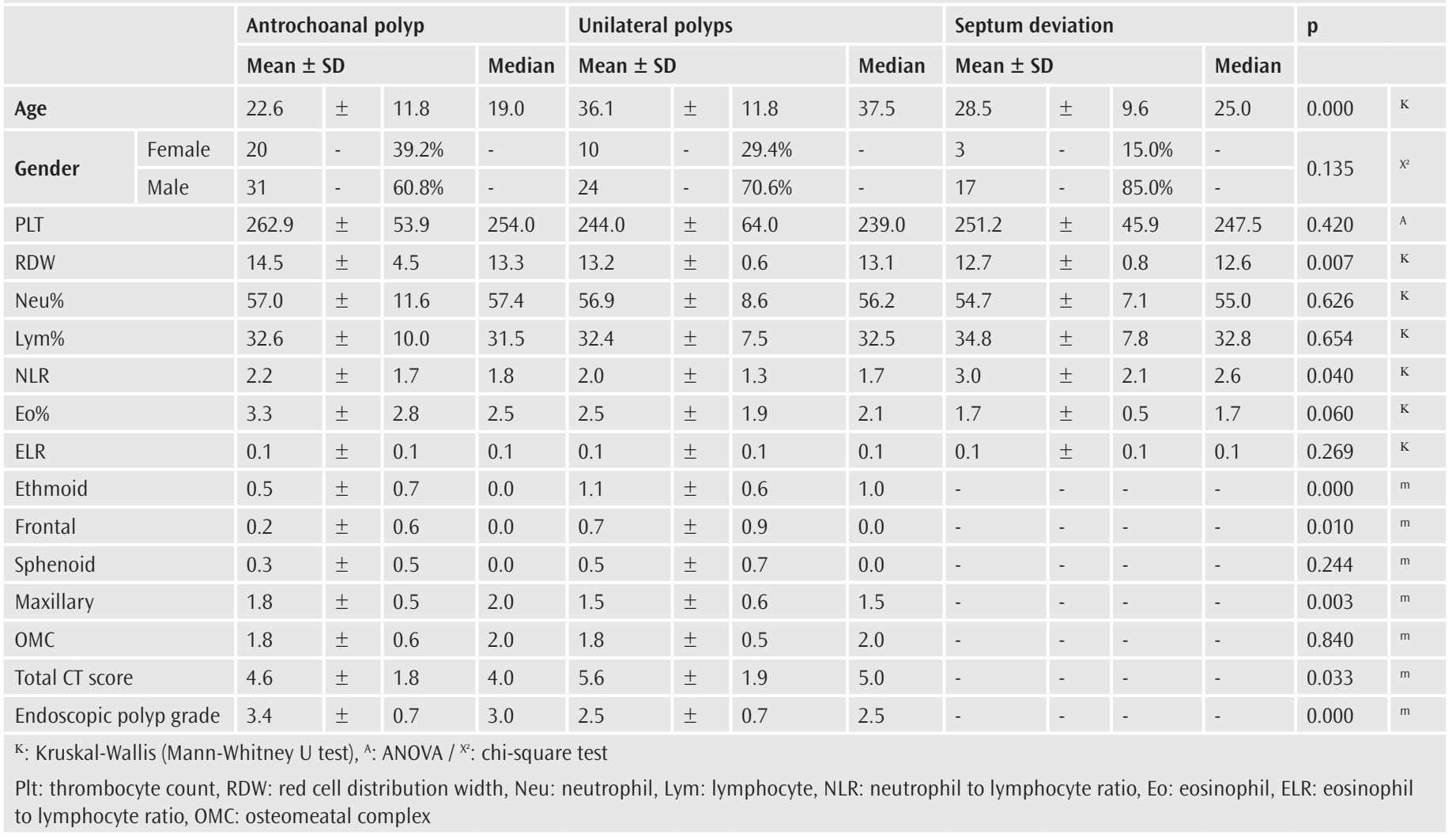


Changes in systemic inflammation parameters in preoperative and postoperative measures may explain the effects of unilateral polyps and antrochoanal polyps on the systemic inflammatory process. Changes in systemic inflammatory parameters may help our timing of the medical or surgical therapy or evaluating the response to the treatment.

\section{Conclusion}

The extent of unilateral sinonasal polypoid disease does not affect the severity of systemic inflammation. The effects of antrochoanal polyps on systemic inflammation are similar to the effects of unilateral sinonasal polyps.

Ethics Committee Approval: Our study was approved by the University of Health Sciences, İstanbul Training and Research Hospital Local Clinical Research Ethics Committee on August 29 ${ }^{\text {th }}$, 2019, with the decision number of 1958 (decision no: 2011-KAEK-50).

Informed Consent: Informed consent was taken from all patients for their surgeries and the use of their medical data in academic medical research.

Peer-review: Externally peer-reviewed.

Author Contributions: Concept - T.K.; Design - T.K., A.V.S., Ö.Y.; Data Collection and/or Processing - T.K., A.V.S., O.Ö.; Analysis and/or Interpretation - T.K., A.V.S., Ö.Y.; Literature Search - T.K., Ö.Y.; Writing Manuscript - T.K.

Conflict of Interest: No conflict of interest was declared by the authors.

Financial Disclosure: The authors declared that this study received no financial support.

\section{References}

1. Fokkens WJ, Lund VJ, Mullol J, Bachert C, Alobid I, Baroody F, et al. EPOS 2012: European position paper on rhinosinusitis and nasal polyps 2012. A summary for otorhinolaryngologists. Rhinology 2012; 50: 1-12.

2. Settipane RA, Peters AT, Chiu AG. Chapter 6: Nasal polyps. Am J Rhinol Allergy 2013; 27: 20-5.

3. Pawankar R. Nasal polyposis: An update. Curr Opin Allergy Clin Immunol 2003; 3: 1-6

4. Berstein JM, Nasal polyps. In: Kennedy DW, Bolger WE, Zinreich SJ, editors. Diseases of the Sinuses diagnoses and Management. Hamilton: B.C. Decker; 2001. p. 69-75.

5. Rinia AB, Kostamo K, Ebbens FA, van Drunen CM, Fokkens WJ. Nasal polyposis: A cellular-based approach to answering questions. Allergy 2007; 62: 348-58.

6. Galluzzi F, Pignataro L, Maddalone M, Garavello W. Recurrences of surgery or antrochoanal polyps in children: A systematic review. Int J Pediatr Otorhinolaryngol 2018; 106: 26-30.

7. Yamashiro Y, Nakamura M, Huang GW, Kosugi T. Presence of urokinasetype plasminogen activator (u-PA) in tissue extracts of antrochoanal polyp. Laryngoscope 1992; 102: 1049-52.

8. Mygind N, Dahl R, Bachert C. Nasal polyposis, eosinophil dominated inflammation, and allergy. Thorax 2000; 55: 79-83.

9. Atan D, Özcan KM, Köseoğlu S, İkincioğulları A, Çetin MA, Ensari S, et al. New predictive parameters of nasal polyposis: Neutrophil to lymphocyte ratio and platelet to lymphocyte ratio. Kulak Burun Bogaz Ihtis Derg 2015; 25: 97-101.
10. Yenigün A. Assessment of patients with nasal polyposis by the neutrophilto-lymphocyte ratio and eosinophil-to-lymphocyte ratio. Kulak Burun Bogaz Ihtis Derg 2015; 25: 193-9.

11. Hopkins C, Browne JP, Slack R, Lund V, Brown P. The Lund-mackay staging system for chronic rhinosinusitis: How is it used and what does it predict? Otolaryngol Head Neck Surg 2007; 137: 555-61.

12. Meltzer EO, Hamilos DL, Hadley JA, Lanza DC, Marple BF, Nicklas RA, et al. Rhinosinusitis Initiative. Rhinosinusitis: developing guidance for clinical trials. J Allergy Clin Immunol 2006; 118(5 Suppl): S17-61.

13. Wittekindt C, Hess A, Bloch W, Sultanie S, Michel O. Immunohistochemical expression of VEGF and VEGF receptors in nasal polyps as compared to normal turbinate mucosa. Eur Arch Otorhinolaryngol 2002; 259: 294-8.

14. Zheng H, Tang L, Song B, Yang X, Chu P, Han S, et al. Inflammatory patterns of antrochoanal polyps in the pediatric age group. Allergy Asthma Clin Immunol 2019; 15: 39 .

15. Chen Z, Peng Y, Ng CL, Jin P, Liu J, Li YY, et al. The clinical characteristics and histopathological features of chronic rhinosinusitis with unilateral nasal polyps in 136 patients in Southern China. Clin Otolaryngol 2018; 43: 1345-9.

16. Kusumanto YH, Dam WA, Hospers GA, Meijer C, Mulder NH. Platelets and granulocytes, in particular the neutrophils, form important compartments for circulating vascular endothelial growth factor. Angiogenesis 2003; 6: 283-7.

17. Avanzas P, Quiles J, Lopez de Sa E, Sanchez A, Rubio R, Garcia E, et al. Neutrophil count and infarct size in patients with acute myocardial infarction. Int J Cardiol 2004; 97: 155-6.

18. Fock RA, Blatt SL, Beutler B, Pereira J, Tsujita M, de Barros FE, et al. Study of lymphocyte subpopulations in bone marrow in a model of protein-energy malnutrition. Nutritio 2010; 26: 1021-8.

19. Tamhane UU, Aneja S, Montgomery D, Rogers EK, Eagle KA, Gurm HS Association between admission neutrophil to lymphocyte ratio and outcomes in patients with acute coronary syndrome. Am J Cardiol 2008; 102: 653-7.

20. Halazun KJ, Aldoori A, Malik HZ, Al-Mukhtar A, Prasad KR, Toogood GJ, et al. Elevated preoperative neutrophil to lymphocyte ratio predicts survival following hepatic resection for colorectal liver metastases. Eur J Surg Oncol 2008; 34: 55-60.

21. Lippi G, Targher G, Montagnana M, Salvagno GL, Zoppini G, Guidi GC. Relation between red blood cell distribution width and inflammatory biomarkers in a large cohort of unselected outpatients. Arch Pathol Lab Med 2009; 133: 628-32.

22. Turkmen K. Platelet-to-Lymphocyte Ratio: One of the novel and valuable platelet indices in hemodialysis patients. Hemodial Int 2013; 17: 670.

23. Ulu S, Ulu MS, Bucak A, Ahsen A, Yucedag F, Aycicek A. Neutrophil-tolymphocyte ratio as a new, quick, and reliable indicator for predicting diagnosis and prognosis of idiopathic sudden sensorineural hearing loss. Otol Neurotol 2013; 34: 1400-4.

24. Bucak A, Ulu S, Oruc S, Yucedag F, Tekin MS, Karakaya F, et al. Neutrophil-tolymphocyte ratio as a novelpotential marker for predicting prognosis of Bell palsy. Laryngoscope 2014; 124: 1678-81.

25. Di Lorenzo G, Drago A, Esposito Pellitteri M, Candore G, Colombo A, Gervasi F, et al. Measurement of inflammatory mediators of mast cells and eosinophils in native nasal lavage fluid in nasal polyposis. Int Arch Allergy Immunol 2001; 125: $164-75$.

26. Matsuwaki Y, Ookushi T, Asaka D, Mori E, Nakajima T, Yoshida T, et al. Chronic rhinosinusitis: Risk factors for the recurrence of chronic rhinosinusitis based on 5-year follow-up after endoscopic sinus surgery. Int Arch Allergy Immunol 2008; 146: 77-81. 
27. Tecimer SH, Kasapoglu F, Demir UL, Ozmen OA, Coskun H, Basut O. Correlation between clinical findings and eosinophil/neutrophil ratio in patients with nasal polyps. Eur Arch Otorhinolaryngol 2015; 272: 915-21.

28. Boztepe OF, Gün T, Demir M, Gür ÖE, Ozel D, Doğru H. A novel predictive marker for the recurrence of nasal polyposis following endoscopic sinus surgery. Eur Arch Otorhinolaryngol 2016; 273: 1439-44.
29. Stammberger H. Surgical treatment of nasal polyps: past, present, and future. Allergy 1999; 54 (Suppl 53): 7-11.

30. Delbrouck C, Gabius HJ, Vandenhoven G, Kiss R, Hassid S. Budesonidedependent modulation of expression of macrophage migration inhibitory factor in a polyposis model: Evidence for differential regulation in surface and glandular epithelia. Ann Otol Rhinol Laryngol 2004; 113: 544-51. 